Article

\title{
Geoheritage and Geotourism Contribution to Tourism Development in Protected Areas of Slovakia-Theoretical Considerations
}

\author{
L'ubomír Štrba *, Jana Kolačkovská, Dušan Kudelas®, Branislav Kršák and Csaba Sidor \\ Institute of Earth Resources, BERG Faculty, Technical University of Košice, Letná 9, 04200 Košice, Slovakia; \\ jana.kolackovska@tuke.sk (J.K.); dusan.kudelas@tuke.sk (D.K.); branislav.krsak@tuke.sk (B.K.); \\ csaba.sidor@tuke.sk (C.S.) \\ * Correspondence: lubomir.strba@tuke.sk; Tel.: +421-55-602-2442
}

Received: 21 February 2020; Accepted: 7 April 2020; Published: 8 April 2020

\begin{abstract}
Slovakia is renowned for its remarkable and rare natural beauty, abundant in natural resources with several noteworthy geological features. However, the protection of nature has primarily been understood as the protection of biodiversity in Slovakia. For the conservation of geological diversity and landforms, very little has been done. Geoconservation or the protection of geodiversity is being applied to specific places known as geosites, where significant earth elements (geological, paleontological, geomorphological, hydrological and pedological) are protected, preserved and managed. Most geosites benefit from existing protected areas. Their protection is random and does not result from the recognition of their values. As discussed in the paper, geotourism related activities can undoubtedly contribute to promoting the protection of geosites in protected areas. Besides, through a geotourism approach, geodiversity can obtain public attention and positively influence the state of protected areas by its activities. Such initiatives not only can improve the protection of geological sites but also can play a crucial role in sustainable tourism development.
\end{abstract}

Keywords: geoheritage; geotourism; tourism development; nature protection; Slovakia

\section{Introduction}

Names such as defense or protecting the homeland denoted the first intentions of protecting rare natural sites in the past $[1,2]$. The idea of preserving remarkable and unique natural phenomena has dominated since the announcement of the first protected areas in the world [3]. Within these first initiatives, the decisive factors in nominating regions to be protected were beauty, magnificence and rarity rather than the criterion the natural value of phenomena [4]. Subsequently, human society became aware of the relationship to the past, which can be expressed not only by art but also through preserved nature, which must be protected. From the human-being perspective, there has been a long-standing perception that nature works independently of human society, so human activities do not affect global natural processes and general features of the environment. However, technical innovations enabled society to use more efficiently natural resources. Protected areas have become islands in an industrial and urbanized landscape with all adverse developmental purposes. In addition to that, only the untouched and undisturbed natural system, such as an old-growth forest, was considered suitable candidate for nature conservation. At the turn of the century, scientists rejected a recognized view and supported the notion that man is part of nature and biodiversity $[5,6]$. Currently, especially from a euro-centric perspective, a view prevails that it is extremely important to know the interactions and relationships of man and biodiversity if we want to protect nature [7-10].

However, the recent situation in many countries is that conservation is understood as biodiversity protection primarily, despite the fact that the natural environment comprises biodiversity and 
geodiversity. Both are equally important. However, compared to the living part of the nature, protection of non-living nature, including geological features and reliefs, seems to be less developed and discussed. Due to the intense focus on biodiversity, the importance of geodiversity has been underestimated. Nonetheless, geodiversity is an essential part of nature and much of the surface biodiversity depends on the subsoil and surface. In this sense, the diversity of inanimate nature, or geodiversity, which consists of a wide range of processes, environments and evolution, strongly supports the diversity and resilience of biodiversity. Therefore, geodiversity should be carefully considered to achieve successful conservation. As stated by Gray [11], geodiversity is of great value for geotouristic and geoeducational activities, especially through geo(morpho)sites, [12,13]. Therefore, the presence of geosites in any area may significantly contribute to the overall tourism attractiveness and development potential as, e.g., Belogradchik Rocks in Bulgaria [14], Postojna Cave in Slovenia [15] or the Uvac Canyon in Serbia [16].

National parks and protected landscape areas are crucial zones for implementing geo-conservation strategies because of their size and importance. As many protected areas have become important tourist destinations, $[17,18]$ they are suitable for raising public awareness of all aspects of nature, biological and geological $[19,20]$. Besides, these protected areas are already recognized by local authorities and people who live and work in such locations.

This work aims to point out the potential benefits of geoheritage presence and contribution of geotourism in protected areas in Slovakia in the context of sustainable development of tourism and nature protection in such areas.

\section{Nature Protection, Tourism and Geoheritage-Literature Overview}

Tourism as an economic activity can generate growth and employment. It also contributes to economic and social development and integration, as regards rural and mountain areas and peripheral and very remote areas [21-25]. In addition to these benefits, the expected growth in tourism and its new trends can make a positive contribution to the sustainability of protected areas and to the development potential of their surrounding areas and local communities. Tourism can become the main instrument for preserving these areas but also for raising awareness of the environment of the population and visitors.

The relationship between tourism and protected areas is as old as the history of protected areas. As mentioned by Wilson et al. (2009) [25], the relationship between tourism and protected areas is complex resulting from the distinct economic focus of tourism on one side and the conservation focus of protected areas on the other side. The importance of this relationship lies in confrontation, which can raise awareness of the value of nature and lead to ecological behavior and conservation activities. Tourism can represent a key role in providing information on protected areas and raising awareness among tourists about the environmental consequences of their activities [26,27] and has a potential to become an important tool for preserving these areas. These positive impacts of tourism can be achieved through funding and education programs, by disseminating appropriate information for tourism participants and residents of protected areas. Various authors e.g., [28,29] refer to the potential positive contribution of tourism in protected areas, which is shown in Table 1. However, risks and negative impacts of tourism in protected areas may occur affecting ecosystems, soils, vegetation, water, air and wildlife [28]. Potential negative effects of tourism in protected areas may include: disruption of wildlife breeding cycles and behaviors, degradation or damage of natural diversity features, destruction of ecosystems, increase of pedestrian and vehicular traffic, soil erosion, noise increase, pollution, water shortage, degradation or loss of natural landscape and historic sites, collection of rare minerals and species [28,30-35]. 
Table 1. Potential benefits of tourism in protected areas [28].

\begin{tabular}{|c|c|}
\hline & Benefits \\
\hline \multirow{5}{*}{$\begin{array}{l}\text { Enhancing Economic } \\
\text { Opportunity }\end{array}$} & Increases jobs for local residents \\
\hline & Increases income \\
\hline & $\begin{array}{l}\text { Stimulates new tourism enterprises and stimulates and diversifies the local } \\
\text { economy }\end{array}$ \\
\hline & Encourages local manufacture of goods \\
\hline & Obtains new markets and foreign exchange \\
\hline \multirow{13}{*}{$\begin{array}{l}\text { Protecting Natural and } \\
\text { Cultural Heritage }\end{array}$} & Improves living standards \\
\hline & Generates local tax revenues \\
\hline & Enables employees to learn new skills \\
\hline & Increases funding for protected areas and local communities \\
\hline & Protects ecological processes and watersheds \\
\hline & Conserves biodiversity (including genes, species and ecosystems) \\
\hline & Protects, conserves and values cultural and built heritage resources \\
\hline & $\begin{array}{l}\text { Creates economic value and protects resources which otherwise have no } \\
\text { perceived value to residents or represent a cost rather than a benefit }\end{array}$ \\
\hline & Transmits conservation values through education and interpretation \\
\hline & $\begin{array}{l}\text { Helps to communicate and interpret the values of natural and built heritage and } \\
\text { of cultural inheritance to visitors and residents of visited areas, thus building a } \\
\text { new generation of responsible consumers }\end{array}$ \\
\hline & $\begin{array}{l}\text { Supports research and development of good environmental practices and } \\
\text { management systems to influence the operation of travel and tourism } \\
\text { businesses, as well as visitor behavior at destinations }\end{array}$ \\
\hline & Improves local facilities, transportation and communications \\
\hline & Helps develop self-financing mechanisms for protected area operations \\
\hline \multirow{8}{*}{ Enhancing Quality of Life } & Promotes aesthetic, spiritual and other values related to well-being \\
\hline & Supports environmental education for visitors and locals \\
\hline & $\begin{array}{l}\text { Establishes attractive environments for destinations, for residents as much as } \\
\text { visitors, which may support other compatible new activities, from fishing to } \\
\text { service or product-based industries }\end{array}$ \\
\hline & Improves intercultural understanding \\
\hline & Encourages the development of culture, crafts and the arts \\
\hline & Increases the education level of local people \\
\hline & Encourages people to learn the languages and cultures of foreign tourists \\
\hline & Encourages local people to value their local culture and environments \\
\hline
\end{tabular}

The positive impact of tourism, in terms of dissemination of information among visitors, goes back to the beginnings of increasing interest and attendance of people in protected areas. This initiated the need to guide their movement in protected areas. Moreover, it was necessary to instruct the visitors in an unforced way, while visitors follow the guide or proceed from one interpretational panel to another along the tourist trail. In this regard, lesser number of restrictions is required to control the movement of tourists in the area. The purpose was to encourage the visitor to understand nature conservation. These reasons led to the formation of the first nature trails in the United States, at Harriman State Park's Station, to identify and study interesting plants, insects and other natural features [36]. Later, especially after World War II, such trails began were built in Germany [37]. 
Inappropriate management of tourism development can lead to negative impacts, which include loss of aesthetic value, increased noise levels, emissions generation, solid waste and littering, deforestation due to building construction, soil erosion, pollution of surface and underground waters and air pollution, ecosystem disruption, destruction of national parks due to use of vehicles and landscape, change thus reducing their attractiveness for visitors.

According to Dingwall, when considering geological heritage, support for geological features is only implicit and included in terms such as natural features, scenery, and ecosystems [38]. In most countries, concerns about the protection of biodiversity are paramount, and in a legal sense, nature protection is essentially synonymous with biological protection. Many international nature conservation organizations, although using the generic term nature conservation, tend to be synonymous with "wildlife conservation". Milton summed up the situation well, stating that diversity in nature is usually considered to be a diversity of living nature [39]. Therefore, in contrast to the protection of biological, aesthetic and cultural values, protection of geoheritage rarely followed national strategy, based on unified criteria and recognition of the scientific value as the main criterion. From the perspective of nature protection, only minor importance was attached to geodiversity because living nature appeared more vulnerable than inanimate nature. Unquestionably, even the inanimate part of nature is undergoing long-term development $[40,41]$.

Not only organizations but also most people associate nature protection with biodiversity protection. Geodiversity protection is an area of nature conservation that is not well understood, but it seems to be changing. There is a very close link between geodiversity and biodiversity. A holistic approach to the conservation of natural diversity can be achieved by managing and preserving both the living and inanimate aspects of the natural world, in contrast to nature conservation towards a traditional biocentric focus. Biodiversity depends on geodiversity. Nevertheless, the geological, geomorphological and pedological basis was practically overlooked. However, this basis is a prerequisite for evolution and development of living nature in any part of the world [11,42,43].

The reworking of the International Union for Conservation of Nature (IUCN) definition of a protected area has brought a fundamental change in its primary focus from biodiversity to a broader nature concept [44]. The contrast between the previous definition and the current definition is evident from the following. Definition of the 1994 protected area is: "an area of land or sea that is specifically dedicated to the protection and conservation of biodiversity, natural and related cultural resources." Current definition: "a clearly defined geographical space that is recognized, reserved and managed by legal or other effective means to achieve long-term nature conservation with associated ecosystem services and cultural values". Subsequently, the Summit in Spain, at the IUCN Protected Areas Summit, in Almeria, discussed the extension of the definition of diversity in the year 2007. The summary of proceedings reflects the statement that 'protected areas should address a range of diversity issues, including the need to protect geological and soil diversity [44].

In summary, IUCN directly recognizes that geodiversity is part of natural diversity, and geological heritage is part of natural heritage. They also acknowledge their scientific, cultural, aesthetic, landscape, economic and intrinsic value, represented by geodiversity and the importance of geodiversity in promoting biological, cultural and landscape diversity.

Natural sites of geo(morpho)logical importance have been visited for a long time [45-47]. Nowadays, the most effective way to promote and protect geoheritage, especially from the tourism development perspective, is geotourism. The concepts of geodiversity and geotourism are related to the geological environment in the abiotic sphere and emphasize the role of geological and geomorphological elements. Sharples pointed out the importance of geoconservation of geodiversity for future generations. Geotourism plays a crucial role in this context because it puts into practice geoconservation and promotes its understanding among the general public [48].

Similarly, authors such as Reynard [49] and Zouros [50] suppose that the protection of geological heritage depends on the public perception that it must be preserved. Therefore, the best way to protect it is to connect the public to the geoheritage. This purpose is stated in the definition of geotourism 
proposed by Hose [51]. Geotourism means providing interpretative facilities and services to promote the value and social benefits of geological and geomorphological sites and their materials and to ensure their protection for use by students, tourists and other occasional vacationers.

Geotourism is a form of cultural and environmental tourism that can develop in areas with sites of significant geological heritage that are used to attract visitors [52-54].

Other authors similarly focus on "geo" in geotourism, which concerns geology and geomorphology and natural resources of the landscape, reliefs, fossil deposits, rocks and minerals, with an emphasis on valuation the processes that have created such functions [55]. The same authors reviewed this definition a few years later, adding that geotourism promotes tourism for geosite and the conservation of geodiversity and the understanding of natural sciences through recognition and learning [56].

The Arouca Declaration (12 November 2011, Portugal; available online at: http://www. europeangeoparks.org/? $p=223$ ) states that geotourism should be defined as tourism that maintains and enhances the identity of the territory, taking into consideration its geology, environment, culture, aesthetics, heritage and the well-being of its inhabitants. Geological tourism is one of several parts of geotourism [57].

To summarize the approaches that have emerged concerning geotourism, it is clear that there are two concepts: (a) sensu stricto (lat. limited) geotourism as a form of tourism aimed at exploring geological phenomena - collecting fossil substances, etc.; (b) sensu lato (lat. in broad terms) geotourism, including all forms of tourism, carried out on Earth; in a geographical sense.

Moreover, as defined by National Geographic, geotourism is also defined as tourism that maintains or enhances the geographical character of a place, its environment, culture, aesthetics, heritage and the well-being of its inhabitants [58].

To bring people, especially general public, closer to geological heritage, geoparks can be considered the most effective places. Here, tourists visit various geological features, use geological walkways and lookout points, geographic activities and visitor centers for "geoinformation". Besides, thanks to the meaningful and unforgettable experiences offered by geoparks, visitors can have a deeper awareness and connection with the geological heritage.

A geopark is a unified area that advances the protection and use of geological heritage in a sustainable way, and promotes the economic well-being of the people who live there [59]. Therefore, a geopark is a territory that represents a heritage, not only from a geological point of view. It can also be important for archaeological, ecological, economic, historical and cultural reasons. All these aspects should be associated with sustainable development [60,61]. Besides, geoparks create opportunities for the development of the local economy. Geoparks have a better connection with local social and cultural life in comparison to national, natural or regional parks [62]. It is also important to note that geoparks are not national protected areas that are dependent on national laws. Recognizing the role of geoparks in sustainable use and protection of geoheritage, many publications on various aspects of this topic have been written in the last decade e.g., [63-71].

\subsection{Nature Protection and Geoheritage in Slovakia}

The territory of Slovakia, thanks to varied geological structure (Figure 1) and complex geomorphological evolution, includes geodiversity of various values (Figure 2, Table 2) that may be used as a remarkable resource of (geo)tourism development not only in geopark areas. However, most of geologically significant sites are not protected in Slovakia [72]. There is no specific act on geoheritage or geosites protection in Slovakia. Therefore, the protection of geoheritage/geosites in Slovakia has to be considered from the broader context of general nature protection. Nature protection in Slovakia is regulated via the Act No. 543/2002 Coll. of 25 June 2002 on Protection of Nature and Landscape [73] and Executive Decree to the Act No. 24/2003 [74]. 


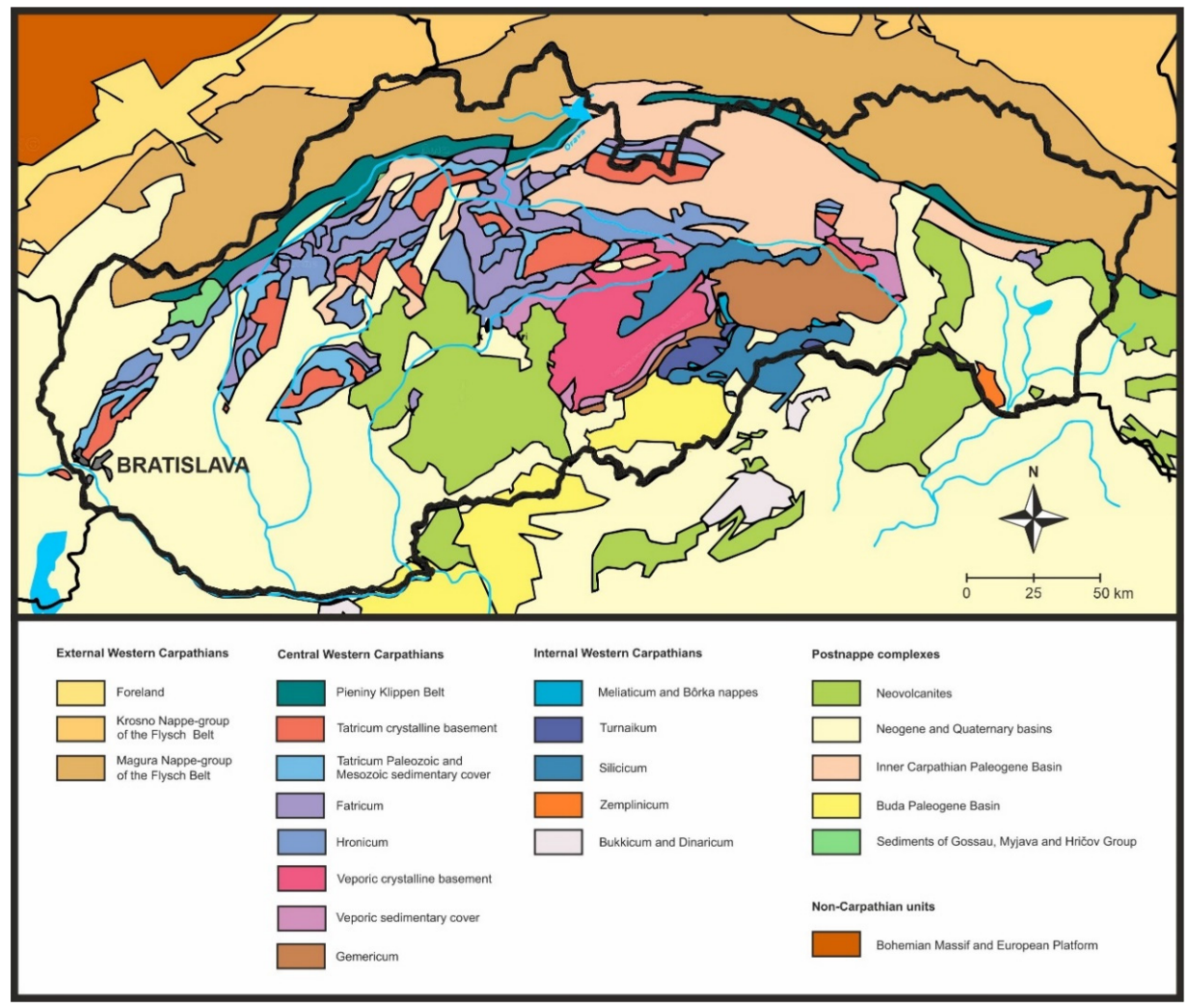

Figure 1. Geological map of Slovakia $[75,76]$.

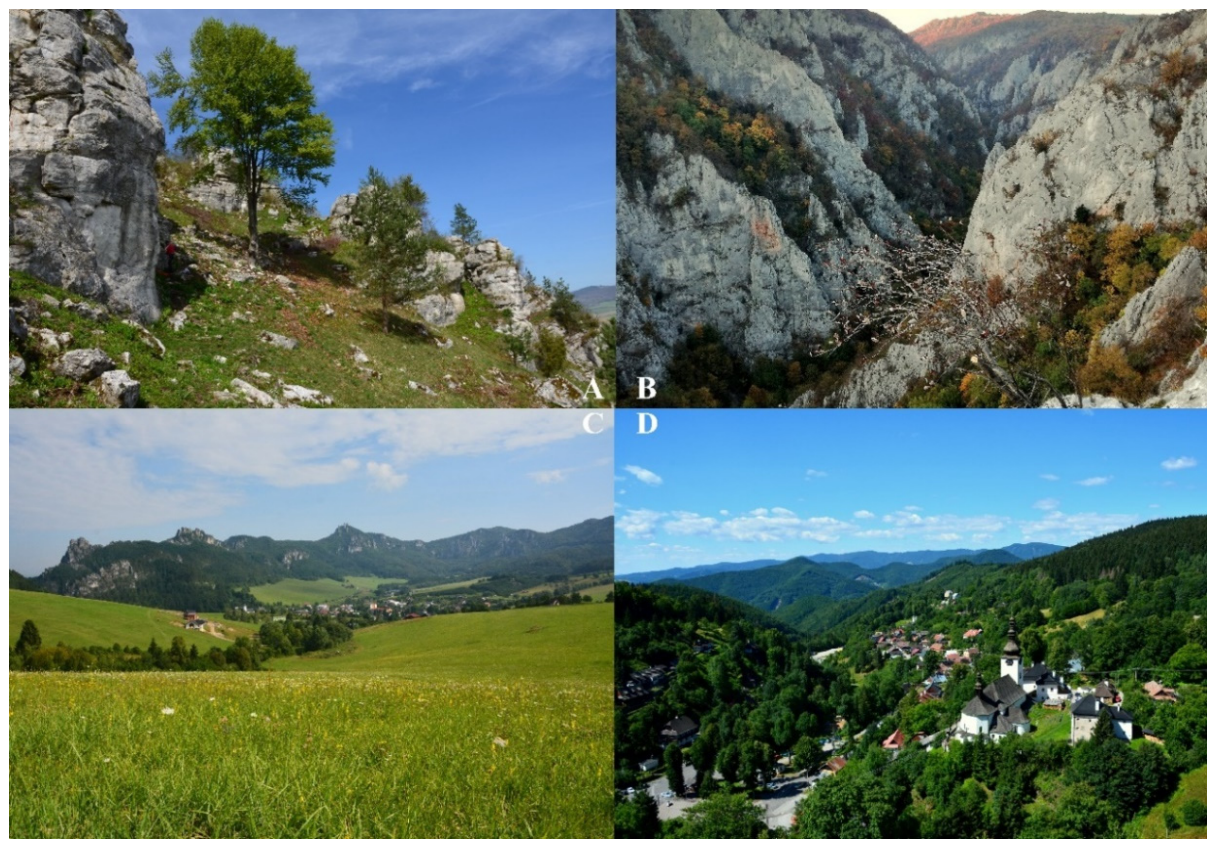

Figure 2. Geodiversity examples in Slovakia, (A): Dreveník (mass movement and rock disintegration, the largest travertine mound in Slovakia, rock towns Peklo (Hell) and Raj (Paradise), caves). (B): Zádielska tiesňava (the deepest (more than $300 \mathrm{~m}$ deep) gorge in Slovakia with more than 120 caves, the highest (105 m tall) pyramid-shaped rock in Slovakia, various karstic features, cliffs and vertical walls). (C): Súl'ovské skaly (rocktown with landforms as rock towers, needles, windows and gates (e.g., the Gothic Gate, $13 \mathrm{~m}$ tall) separated by deep waterless gorges, ravines and valleys formed by chemical and mechanical weathering), (D): Špania Dolina valley (cooper and silver ore deposits mined in the past, Museum of copper, historical mining site). 
Table 2. Examples of geodiversity values in Slovakia.

\begin{tabular}{|c|c|c|}
\hline Value Type & Character & Example \\
\hline \multirow[t]{3}{*}{ Cultural } & Folklore & Král'ova hol'a, Banská Štiavnica, Hrušov \\
\hline & Archaeological/historical & Čertova pec, Aksamitka Cave, Dzeravá skala \\
\hline & Spiritual & Mariánska hora in Levoča, Skalka at Trenčín \\
\hline \multirow[t]{4}{*}{ Aesthetics } & local landscape & Špania dolina, Hodruša-Hámre \\
\hline & Geotourism & Šomoška, Dreveník \\
\hline & free-time activities & climbing, skiing, tourism \\
\hline & artistic inspiration & Zádiel Gorge, Súl'ovské skaly (rocks) \\
\hline \multirow[t]{6}{*}{ Economic } & Energy & brown coal, lignite \\
\hline & industrial minerals & kaolinite, halite \\
\hline & Metals & iron ore, cuprum ore \\
\hline & construction materials & dolomite, limestone \\
\hline & precious stones & silver, gold, precious opal \\
\hline & Fossils & Cerová-Lieskové, Marianka, Vyšné Ružbachy \\
\hline \multirow[t]{8}{*}{ Use } & Plateau & construction and infrastructure on land \\
\hline & storage space & waste, oil trap \\
\hline & Health & Bardejovské Kúpele spa, Piešt'any (spa) \\
\hline & chemical properties of water & mineral waters, e.g., Cígel'ka \\
\hline & soil function & Viniculture \\
\hline & geosystem function & fluvial processes \\
\hline & ecosystem function & scientific value of biodiversity \\
\hline & pollution control & climate changes \\
\hline \multirow[t]{3}{*}{ Scientific } & geoscience research & geoprocesses \\
\hline & history research & early identification of non-conformities \\
\hline & education, training & professional training, excursions \\
\hline
\end{tabular}

However, in the Act nor in the Decree, there is no mention about geosite. However, to stay objective, geological objects are mentioned several times in the Act, e.g., in $\S 2$ par. 2, letter b, ecosystem rock and minerals (rocks, minerals, fossils, morphology forms, soil types, lakes, springs, ponors, geysers) are mentioned; in letter c, significant landscape element or a part of a territory creating characteristic landscape or contributes to its ecological stability (peatbog, cliff, gorge, block sea, sand dune) is mentioned; $§ 24$ of this act declares cave and waterfall as a natural monument; and according to $\S 33$ par. 2, mineral and fossils are included among a protected species [73].

This Act defines large-scale and small-scale areas or sites of nature protection: national park, protected landscape area, protected area, nature reserve, national nature reserve, natural monument, national natural monument, protected landscape element, and protected bird area [73]. The total number of 9 national parks, 14 protected landscape areas (Figure 3) cover 1,102,713 ha, representing $22.5 \%$ of the area of Slovakia. 


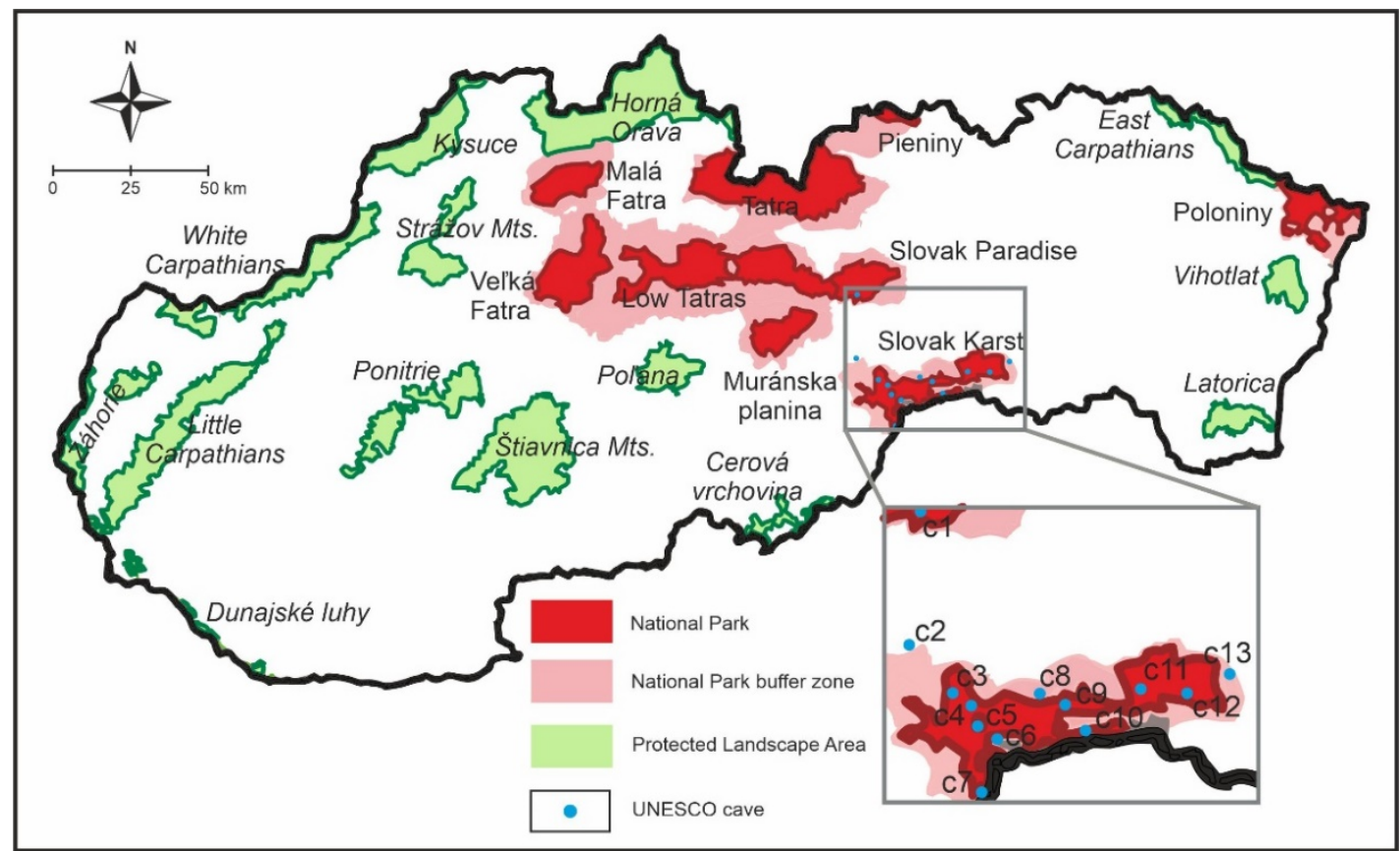

Figure 3. Large-scale protected areas in Slovakia and Slovak caves of UNESCO World Heritage List, c1: Dobšinská Ice Cave, c2: Ochtinská Aragonite Cave, c3: Zvonivá jama, c4: Diviačia priepast', c5: Gombasecká Cave, c6: Silická l'adnica, c7: Domica Cave, c8: Krásnohorská Cave, c9: Hrušovská Cave, c10: Obrovská priepast', c11: Snežná diera, c12: Skalisktý potok - Kunia priepast', c13: Jasovská Cave, c14: Drienovská Cave [77].

Kilík [78] states that, although the title of the Act also mentions the protection of the landscape, the law does not deal with it practically. The law should clearly define competences and obligations of stakeholders. Many protected geological sites gain benefits from other protective frameworks that already exist in their territories (national parks, biosphere reserves and others) [72]. These allow the preventive conservation of geological and geomorphological sites.

A National Nature Monument or Nature Monument is usually used to protect remarkable geological or geomorphological elements of heritage in Slovakia. Due to their size and importance, national parks and protected landscape areas are crucial areas where geoconservation strategies need to be implemented and public awareness raised of all aspects of nature, biological and geological nature [19]. The following tables (Tables 3 and 4) show numbers of important geological sites that are part of large-scale protected areas and small-scale protected areas in Slovakia.

Table 3. Number of important geological sites within the large-scale protected areas in Slovakia [79].

\begin{tabular}{cc}
\hline Location & Number of Important Geological Sites \\
\hline Protected Landscape Area & 84 \\
National Park & 65 \\
Buffer Zone of the National Park & 28 \\
\hline
\end{tabular}

Table 4. Number of important geological sites within the small-scale protected areas in Slovakia [79].

\begin{tabular}{cc}
\hline Location & Number of Important Geological Sites \\
\hline National Nature Monument & 6 \\
Nature Monument & 4 \\
Buffer Zone of Nature Monument & 1 \\
National Nature Reserve & 13 \\
Nature Reserve & 7 \\
\hline
\end{tabular}


The Geological Institute of Dionyz Stur has identified assemblage of geological sites within the Slovak Republic. The database (available online at: https://apl.geology.sk/g_vgl/?jazyk=en) includes 480 sites [79], which are divided into nine categories according to their character (Table 5). Most of the stratigraphic and paleontological sites are not protected by law, but these sites are characterized by scientific, educational and aesthetic value. As well, they have the potential to become not only an important geological heritage site in Slovakia but also in Europe [80]. Each site record contains detailed geological characteristics of the site, degree and reason of protection, localization on the tourist as well as geological map.

Table 5. Important geological site categories and their number in Slovakia [79].

\begin{tabular}{cc}
\hline Category & Number \\
\hline Mineralogy & 63 \\
Basic geology & 189 \\
Geomorphology & 44 \\
Paleontology & 20 \\
Archaeology & 7 \\
Volcanites & 88 \\
Mining & 27 \\
Hydrology & 37 \\
Tectonics & 5 \\
\hline
\end{tabular}

As reported by Lukáč and Baláž [81], 271 of important geological sites in Slovakia defined by the State Geological Institute of Dionyz Stur are not a subject of any protection according to the Act on Protection of Nature and Landscape [73].

\subsection{Tourism in Protected Areas in Slovakia}

The first program for building educational trails and educational sites was developed in Slovak protected areas in 1984 [82]. As summarized by Bizubová and Nevřelová [83], based on the state program, guides to educational trails had more or less uniform design with a polythematic focus and similar content with a strong emphasis on nature conservation. The educational trails were distinguished according to the length of short (up to $5 \mathrm{~km}$ ), medium (up to $15 \mathrm{~km}$ ) and long (over $15 \mathrm{~km}$ ). It could also be nature trails with the possibility of guide service, without or combined. At that time, 15 educational trails and 20 educational sites were created at a similar ideological and technical level in Slovakia, of which 15 were accessible caves. These include the Jasovska Cave, opened for the first time in 1846, or the first nature trail of Slovakia, which was built in the National Nature Reserve Dunajec Breach in 1960. Over time, many other hiking trails were created that served people as an educational opportunity [84]. Since the end of the 20th century, other organizations have been among the implementers of nature trails and other activities included in the information system of nature trails in Slovakia. In addition to the State Nature Conservation and the Slovak Environmental Agency, these are, e.g., Administration of Slovak Caves, State Forests of the Slovak Republic, individual forest plants, municipalities, micro-regions, various interest groups, civic associations, schools, or individuals [83].

Because it was particularly important to think about environmental education, the first school in Gbelany was established in 1979, thanks to Mr. Pagac. The school intended to provide environmental education for professionals and the general public [84].

Nowadays, information centers perform similar tasks as the school in Gbelany. Unfortunately, according to the Enviroportal (Information portal of the Ministry of Environment of the Slovak Republic, accessible at: https://www.enviroportal.sk/en/about-enviroportal) only half of the protected-large areas have information centers. As a result, we lose one of the exceptional opportunities for guiding and educating visitors [85].

As reported in the latest State of The Environment in the Slovak Republic [80], for tourists, the most attractive destinations are the national parks, yet these are potentially the most vulnerable to 
tourist activity. From the tourism and recreation perspective, national parks and protected areas are currently the subjects of increasing interest. All this suggests that the trend of interest in protected areas will proceed in the coming years [30]. This is confirmed by the state of the environment reports of the Slovak Republic, according to which we can observe for several years, that the most attractive areas for tourism include national parks [86]. The environmental impact of tourism can be notably observed in these areas with intensive tourism, also because the intensity of tourist attendance is not equally distributed in protected areas. Besides, the concepts of zoning and carrying capacity of the territory are yet to be implemented in the majority of protected areas of Slovakia. Areas for mountain tourism activities are concentrated in the territory of Tatra NP, NP Low Tatras and NP Mala Fatra.

The motives to visit Slovakia that predominated among foreign visitors were: interest in highly valued natural sites and activities in compliance with the requirements of sustainable development [86]. This reflects the growing interest in the quality of the natural environment and the need for lower environmental impacts of tourism. Concerning this, we can observe the increasing interest in nature-based alternative forms of tourism such as ecotourism, geotourism, rural tourism and others for several years. These forms of sustainable tourism are one of the ways to decrease negative impacts on nature. It also represents sustainable economic development for the protected area. McKercher [87] refers to several reasons to support sustainable tourism:

1. Focuses on the quality of the experience;

2. The basis of the products comprise the local resources of the protected area (culture, traditions, shops and others);

3. Favors nature-friendly behavior;

4. Provides employment opportunities for the local population;

5. Allows local people to participate in development and decision-making;

6. Supports the preservation of natural and cultural values by providing economic incentives;

7. Allows the visitor contact with the region and increases interest in the environment [87].

National parks and protected areas in Slovakia are currently the subjects of increasing levels of tourism and recreation. According to the Statistical Office of the Slovak Republic, a quarter of tourism in the country is concentrated in the Bratislava Region. However, it is more important for us that the second-highest tourist attendance has been shown for a long time by the Žilina Region (north-western part of the country), followed by the Prešov Region (north-eastern part of the country) [88]. In Slovakia, these two regions are of the highest concentration of areas with nature-based tourism attractiveness and potential (national parks, protected landscape areas, internationally protected areas). As well, the highest area concentration of accommodation facilities includes a compact continuous area of the High, West and Low Tatras, the Great and Small Fatra with adjacent areas of the Poprad, Liptov, Turčianska Basin and the Horehronie valley. This area of northern Slovakia is a gate to many protected areas. It records a total of 4-5 million overnight stays in accommodation facilities, which represents approximately $40 \%$ of the total number of overnight stays in Slovakia [89]. The highest share in the demand is the High Tatras region, which is the target region for visiting the Tatra National Park [88]. However, the total number of tourists in protected areas in Slovakia are only estimations based on one-day-counting of tourists/visitors at specific locations in protected areas. Such methodology is absolutely inaccurate, strongly depending on specific conditions during the day. Therefore, the final estimation of the total number of tourists in protected area per year may significantly differ from reality. According to internal data of State Forests of the Tatra National Park, Figure 4 shows the numbers of tourists in the high mountain range of the Tatra NP during the counting day in August. 


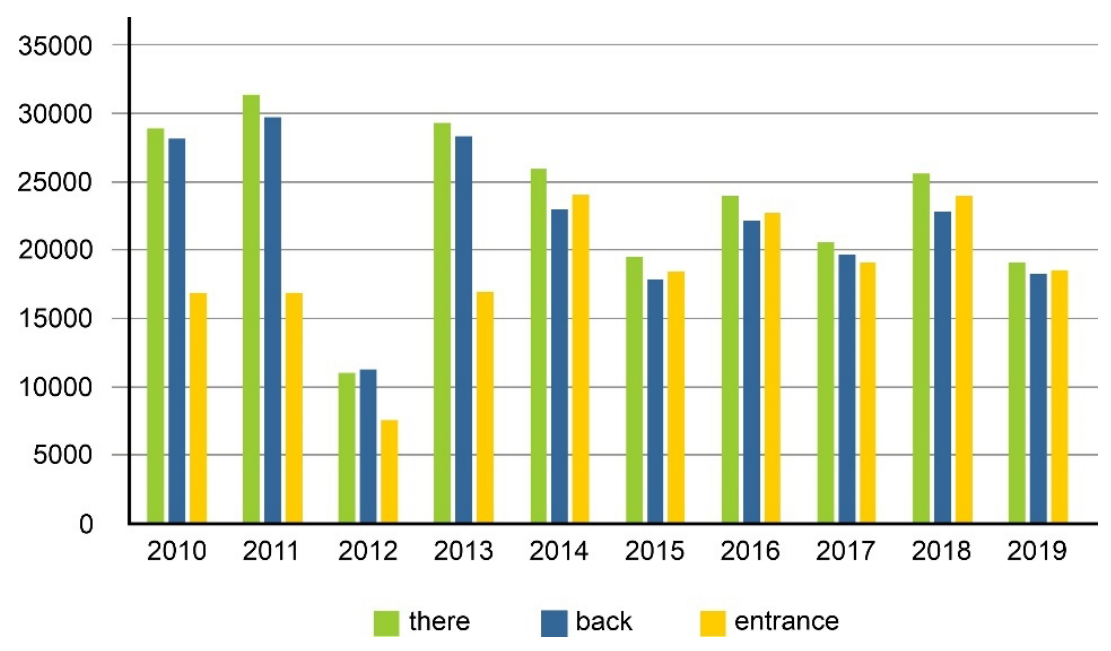

Figure 4. Numbers of tourists (one day counting) in the high mountain area of the Tatra National Park [source: internal data of State Forests of the Tatra National Park].

Cognition of the visitor's motives [54,88-91] is one of the measures that will contribute to recognizing possible negative impacts of tourism activities on natural and cultural-historical resources. In Slovakia, there is a large proportion of foreign transit visitors or overnight visitors who represent a group contributing relatively less to the overall tourism income [88]. Besides, they cause congestion of main traffic routes, which contributes to the negative impact on the environment. On the contrary, short and long-term visitors bring a considerable economic effect, as they have higher expenses on accommodation and catering facilities and other additional services. They thus positively influence the development of tourism and replace the possible burden on the environment to a certain extent [88].

As reported in the latest available State of the Environment in the Slovak Republic, a positive fact concerning the natural environment is that the number of sites designated for mountain tourism activities has stagnated or slightly have increased since 2001. By contrast, the number of accommodation facilities is increasing in the long term $[86,88]$.

A significant environmental problem is an increase in the length of marked hiking trails affected by erosion, which are located above the upper boundary of the forest. The reason is unfavorable conditions of soil and vegetation regeneration due to extreme climatic conditions [86,88]. Critical soil erosion occurs in the territory of NP Low Tatras, NP Mala Fatra, NP Muranska Planina and in the territory of Tatra NP. Although erosion has a rising trend in recent years, the situation has stabilized. Lately, there has been an increase in the length of erosion of the affected cycle paths. It concerns to the cycling routes in NP Pieniny, NP Low Tatras and Tatra NP [86].

The endangering of small-scale protected areas due to tourism activities in the years 2000-2015 was most apparent in the areas of the Tatra NP, NP Low Tatras, NP Mala Fatra, NP Pieniny and NP Slovak Paradise. Within the Protected Landscape area, it was mainly the Protected Landscape Area of Dunajské luhy, Protected Landscape Area of Malé Karpaty, Protected Landscape Area of Strážovské vrchy, Protected Landscape Area of Pol'ana, Protected Landscape Area of Cerová vrchovina and Protected Landscape Area of Vihorlat [86].

\section{Discussion}

Nature provides space and conditions for human life, for its activities, for satisfying its needs. Man transforms nature by exploiting it. One must constantly adapt to the changes that have occurred. The impact of its activities on nature and biodiversity has increased considerably in the last century [92]. Individual factors, such as human activity, natural disturbances and disasters, rarely act independently on nature. The point is mostly a synergistic effect [7]. Moreover, environmental degradation affects not only biodiversity but also geodiversity, which is its precondition. 
According to Ložek, a rich natural heritage becomes a victim of today's inconsiderate civilization. This also occurs in places where there is no economic justification [93]. Zweckbronner refers to the fact that the relationship of man and technology to nature can be described as exploitation at the turn of the 17th and 18th centuries; later as exploitation; at present, it is capture and manipulation [94]. Nature can exist without human society, but its protection can only work in connection with human society [95]. In this regard, the need to discuss the importance of environment, both living and abiotic, is more than actual.

Tourism has the ability to provide people contact with nature and the environment. This confrontation can spread awareness of environmental issues, the value of nature and lead to environmental behavior and environmental protection activities $[27,96,97]$. However, for the well-preserved and most valuable parts of nature, the widest range of restrictions are often adopted as shown in the Table 6 on the example of Slovakia. Such strict protection rules in the most valuable areas in Slovakia, which often have the highest geotourism development potential (e.g., NP Slovak Karst vs. area of potential Silica Geopark, PLA Vihorlat and PLA Latorica vs. area of potential Zemplín Geopark), significantly limit tourism development activities. A harmonious relationship between nature and tourism is possible, in particular, through appropriate management, a clear protection strategy and a suitable policy tool for tourism, e.g., [98-101].

Table 6. List of tourism activities in connection with different levels of protection according to the valid act for the protection of nature and landscape.

\begin{tabular}{|c|c|c|c|c|}
\hline Level of Protection & II. & III. & IV. & V. \\
\hline $\begin{array}{l}\text { Building and marking tourist paths, nature trails, running tracks, skiing } \\
\text { tracks, bicycle trails or motor-roads. }\end{array}$ & A & A & A & A \\
\hline Placement of a short-term mobile facility, for example a stall, pent roof. & A & A & A & A \\
\hline $\begin{array}{l}\text { Installation of information, advertisement and other promotion boards, } \\
\text { outside the urban areas of municipalities. }\end{array}$ & A & A & $\mathrm{P}$ & $\mathrm{P}$ \\
\hline $\begin{array}{c}\text { Illumination of running tracks, skiing tracks and sports areas outside } \\
\text { closed buildings. }\end{array}$ & - & A & A & $\mathrm{P}$ \\
\hline $\begin{array}{l}\text { Organizing of public sports and tourist events and other social events } \\
\text { accessible to the public outside the urban areas of municipalities or } \\
\text { outside sports and recreational areas designed for the above events. }\end{array}$ & A & $\mathrm{P}$ & $\mathrm{P}$ & $\mathrm{P}$ \\
\hline $\begin{array}{l}\text { Movement off marked tourist paths or nature trails outside urban areas } \\
\text { of municipalities. }\end{array}$ & - & $\mathrm{P}$ & $\mathrm{P}$ & $\mathrm{P}$ \\
\hline $\begin{array}{c}\text { Camping, bivouacking, horse riding, lighting a fire, rock climbing, } \\
\text { skialpinism or other sports activities outside the urban areas of } \\
\text { municipalities. }\end{array}$ & - & $\mathrm{P}$ & $\mathrm{P}$ & $\mathrm{P}$ \\
\hline Placement of a construction. & - & - & $\mathrm{P}$ & $\mathrm{P}$ \\
\hline Disturbing peace and quiet. & - & - & - & $\mathrm{P}$ \\
\hline
\end{tabular}

A-approval of the nature protection authority is required; $\mathrm{P}$-activities are prohibited; - restriction is not mentioned in the act, (edits by: the act for the protection of nature and landscape).

According to the Tourism Development Strategy of the Slovak Republic until 2020, the strategic goal of tourism in Slovakia until 2020 is to increase the competitiveness of tourism and thus to make better use of its potential. One of the tasks of competitiveness is the creation of tourism products using the natural potential of the country with regard to the limits of protected areas. In addition, supporting new national tourism products based on active leisure is preferred. Another aim of the task is to create specific regional tourism products focused on (1) soft forms of tourism, (2) typical local activity, (3) experience programs for visitors, and (4) the creation and maintenance of quality educational trails.

Geotourism development related activities, based on the presence of geological heritage in protected areas, is one of the potential solutions of several aims of the tourism development strategy document in Slovakia. As national parks have been among the most attractive tourist areas in Slovakia in last several years, the impact of tourism on the environment can be most clearly observed in these areas with intense tourism as discussed by, e.g., Pickering et al. [102]. However, geotourism is one 
of the tourism forms using the natural potential of the country with regard to the limits of protected areas. Regarding effective use of geoheritage for (geo)tourism development, it is crucial to consider various aspects affecting geosite visits as discussed by various authors [53,103-105]. Here, it must be said that potential visitors of geosites from different countries may prefer different criteria. In Slovakia, according to the study of Štrba, the following criteria are the most important to visit geosite: visual attractiveness of locality, access, visit safety, uniqueness/rarity, information availability, tour/visit difficulty, time-limited visit, tour/visit length, possibility to gain knowledge and number of tourists [53]. Such criteria are met in areas of geoparks presenting various features of geodiversity and related cultural and historical aspects.

The basic conceptual documents relating to geopark management in Slovakia are the Concept of Geoparks in the Slovak Republic, approved by the Government Decree No. 740 of 15 October 2008 and the Update of the Concept of the Geoparks in the Slovak Republic approved by Government Decree No. 4607-2014 of 5 January 2015. 15/2015. According to these documents, seven territories with potential of geopark establishment were defined in Slovakia:

(1) Solivar-Dubnik area in Slanské vrchy Hills, where world-famous precious opal was mined until 1922 near Červenica, and historically important salt deposit in Solivar.

(2) Zemplín Geopark in the Zemplín Hills and its surroundings with examples of rock complexes as well as examples of old mining activity. The Tokaj wine region also extends to the Zemplin Geopark.

(3) Sandberg-Pajštún area in the Little Carpathians Mts., including the following locations: Sandberg, Wietov Quarry and Devin and on the other side the slate site in Marianka and the Pajštún Castle—in this area, the Sandberg-Pajštún Geopark has been officially opened in 2015.

(4) Spiš-Gemer area, predominantly located in the Slovak Paradise National Park, where it will also include demonstrations of old mining activity and metallurgy and some important cultural monuments of Spiš Region.

(5) Silica Plateau area situated in the western part of the Slovak Karst National Park within the Silica Plateau with already built educational trails and educational sites (Domica, Gombasek Cave, Silica Ice Cave, Krásna Hôrka Cave).

(6) Medzev-Jasov area located in the eastern part of the Slovak Karst National Park within the Zádiel and Jasov Plateau with phenomena such as the Jasov Cave and Zádiel Gorge, Háj Gorge, Turňa Castle Hill, Jasov Rock and Jasov Monastery with its surroundings.

(7) Súl'ov-Manín Geopark in the Protected Landscape Area of Strážovske vrchy, centered on Súl'ov Rocks, Manínska Gorge and Kostolecká Gorge, already with partly built infrastructure of environmental education.

As can be seen in the above-mentioned list, the majority of potential geopark areas in Slovakia, at least partially, overlap protected area(s) (Figure 5). The establishment of geoparks thus seems to be a good opportunity for Slovakia to achieve geoconservation of its resources and as well to support the sustainable development of its regional areas. The natural features of a country are very vulnerable. Sustainable use is one of the options if we want this resource preserved and used in the long term. Therefore, geoconservation is an essential point in the development of geotourism in vulnerable areas, such as protected areas in Slovakia. 


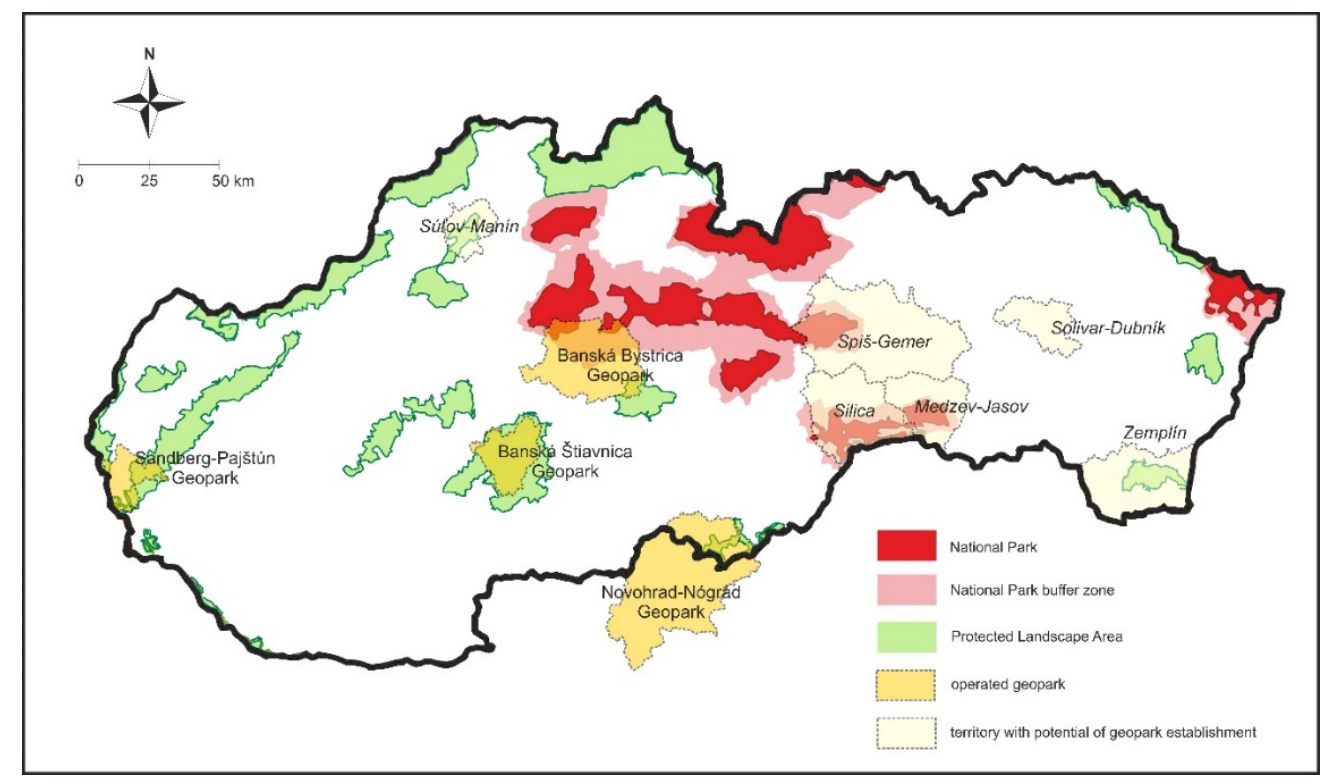

Figure 5. Location of geoparks and territories with potential of geopark establishment compared to large-scale protected areas in Slovakia [77,106,107].

The necessity to build and operate geoparks in Slovakia has been highlighted in the Programme Statement of the Slovak Government in 2012. However, a major problem in the development of geoparks in Slovakia is that geoparks are under-capitalized and that there is currently no direct financial support or other regular subsidy mechanism for their management, which is currently implemented by interest associations of legal entities or civic associations [108].

\section{Conclusions}

Knowledge and awareness of nature protection have been improving in Slovakia during the last decade [109-113]. However, appropriate strategies are still needed for managing and ensuring the survival of wildlife, landscapes, and reliefs. Slovakia has numerous protected areas managed by the State Nature Conservancy of the Slovak Republic. However, many of the abiotic natural phenomena are subjects of no legal protection $[72,78,81]$. Geological heritage located in protected areas is often a place of significant tourism and recreation potential [11,54,55]. Effectively adopting geotourism principles [114], geotourism and geoheritage promotion and geoconservation may undoubtedly contribute to tourism development, on one hand, and to natural heritage protection, on the other.

In this regard, owing to the limited work and cooperation between current biodiversity conservationists and Earth scientists, it is important to integrate and connect biotic and geological conservation, for instance, by suggesting geoconservation in precisely these protected areas that are already recognized by local authorities and people living and working in them. If we want to give a post to geodiversity and geological heritage directly in the nature conservation program, the geoconservation community must work to ensure that geodiversity and geological heritage in protected areas take on considerable importance in the local, national and international context. Activities related to the effective development of geotourism can significantly contribute to this, in terms of geotourism concept. However, one of the key questions "Why should people visit geosites?" should be answered before planning geoheritage based tourism development in any area. In this field, still just a limited number of relevant publications is available [52,53,90,91,103-105,115-119]. As concluded by Różycka and Migoń [91], different types of visitors may have different reasons and motivations, not necessarily focused on geoheritage values. Hence, they will perceive geosites in various ways. However, these reasons may be interrelated since various values are often coupled. Therefore, when considering 
geoheritage's potential contribution to the development of nature-based forms of tourism, much more research focused on potential geosite visitors is required to have relevant data from the demand side.

Author Contributions: Conceptualization, J.K. and L.Š.; investigation, J.K., L.Š., D.K., B.K. and C.S.; resources, J.K., L.Š., D.K., B.K. and C.S.; writing—original draft preparation, J.K. and L.Š.; writing-review and editing, L.Š., J.K., B.K. and C.S.; supervision, L.Š.; project administration, L.Š. and J.K.; funding acquisition, L.ك̌. and D.K. All authors have read and agreed to the published version of the manuscript.

Funding: This publication has been supported by the project KEGA No. 036TUKE-4/2019.

Acknowledgments: Authors would like to thank four reviewers for their comments, suggestions and notes that significantly helped to improve the original version of the paper. Authors would like to thank Mr. Pavol Pitoňák from State Forests of the Tatra National Park for providing internal data of counting the tourists.

Conflicts of Interest: The authors declare no conflict of interest.

\section{References}

1. Little, E.L. Rare and Local Trees in National Forests; U.S. Department of Agriculture-Forest Service: Washington, DC, USA, 1977; 14p.

2. Jongman, R.H.G. Nature conservation planning in Europe: Developing ecological newtorks. Landsc. Urban Plan. 1995, 32, 169-183. [CrossRef]

3. Mcneely, J. Protected areas for the 21st century: Working to provide benefits to society. Biodivers. Conserv. 1994, 3, 390-405. [CrossRef]

4. Lovejoy, T.E. Protected areas: A prism for a changing world. Trends Ecol. Evol. 2006, 21, 329-333. [CrossRef] [PubMed]

5. Vološčuk, I. Ochrana Prírody a Krajiny; Technical University of Zvolen: Zvolen, Slovakia, 2005.

6. Maclaurin, J.; Sterelny, K. What Is Biodiversity? The University of Chicago Press: Chicago, IL, USA, 2008; $217 p$.

7. Urban, P. Nie je ochrana ako ochrana. Alebo všetkého vel'a škodí. In Príroda a Jej Ochrana v Priereze Času, Zborník z Medzinárodnej Vedeckej Konferencie; Slovenské Múzeum Ochrany Prírody a Jaskyniarstva: Liptovský Mikuláš, Slovakia, 2018; pp. 83-106.

8. Wang, Y.; Kotze, D.J.; Vierikko, K.; Niemelä, J. What makes urban greenspace unique-Relationships between citizens' perceptions on unique urban nature, biodiversity and environmental factors. Urban For. Urban Green. 2019, 42, 1-9. [CrossRef]

9. Bridgewater, P.; Rotherham, I.D. A critical perspective on the concept of biocultural diversity and its emerging role in nature and heritage conservation. People Nat. 2019, 1, 291-304. [CrossRef]

10. Peters, M.K.; Hemp, A.; Appelhans, T.; Becker, J.N.; Behler, C.; Classen, A.; Detsch, F.; Ensslin, A.; Ferger, S.W.; Frederiksen, S.B.; et al. Climate-land-use interactions shape tropical mountain biodiversity and ecosystem functions. Nature 2019, 568, 88-92. [CrossRef]

11. Gray, M. Geodiversity: Valuing and Conserving Abiotic Nature, 2nd ed.; Willey-Blackwell: Hoboken, NJ, USA, 2013.

12. Pralong, J.P. Valorisation et vulgarisation des sciences de la Terre: Les concepts de temps et d'espace. In Géomorphologie et Tourisme, Actes de la Réunion Annuelle de la Société Suisse de Géomorphologie (SSGm); Reynard, E., Holzmann, C., Guex, D., Summermatter, N., Eds.; Institut de Géographie: Lausanne, Switzerland, 2003; pp. 115-127.

13. Pralong, J.P.; Reynard, E. A proposal for a classification of geomorphological sites depending on their tourist value. II Quat. 2005, 18, 315-321.

14. Tronkov, D.; Sinnyovsky, D. Belogradchik Rocks, Bulgaria: Geological Setting, Genesis and Geoconservation Value. Geoheritage 2012, 4, 154-164. [CrossRef]

15. Tičar, J.; Tomić, N.; Berg Valjavec, M.; Zorn, M.; Marković, S.B.; Gavrilov, M.B. Speleotourism in Slovenia: Balancing between mass tourism and geoheritage protection. Open Geosci. 2018, 10, 344-357. [CrossRef]

16. Bozić, S.; Tomić, N. Canyons and gorges as potential geotourism destinations in Serbia: Comparative analysis from two perspectives-General geotourists' and pure geotourists'. Open Geosci. 2015, 7, 531-546. [CrossRef]

17. Dharmaratne, G.S.; Sang, F.Y.; Walling, L.J. Tourism potentials for financing protected areas. Ann. Tour. Res. 2000, 27, 590-610. [CrossRef] 
18. Whitelaw, P.A.; King, B.E.M.; Tolkach, D. Protected areas, conservation and tourism-Financing the sustainable dream. J. Sustain. Tour. 2014, 22, 584-603. [CrossRef]

19. Brilha, J. Geoconservation and protected areas. Environ. Conserv. 2002, 29, 273-276. [CrossRef]

20. Bushell, R.; McCool, S. Tourism as a tool for conservation and support of protected areas: Setting the agenda. In Benefits Beyond Boundaries: Tourism E Protected Areas; Bushell, R., Eagles, P.J., Eds.; CABI Press: Wallingford, UK, 2007; pp. 12-26.

21. Tudoran, A.; Petroman, C.; Ciolac, R.; Marin, D. Determining the social and economic importance of rural tourism. Lucrări Științifice. Management Agricol 2019, 21, 192-195. Marin, D. Study on the economic impact of tourism and of agrotourism on local communities. Res. J. Agric. Sci. 2015, 47, 160-163.

22. Lundmark, L. Economic Restructuring into Tourism in the Swedish Mountain Range. Scand. J. Hosp. Tour. 2005, 5, 23-45. [CrossRef]

23. Blackman, A.; Foster, F.; Hyvonen, T.; Jewell, B.; Kuilboer, A.; Moscardo, G. Factors contributing to successful tourism development in peripheral regions. J. Tour. Stud. 2004, 15, 59-70.

24. Moscardo, G. Peripheral Tourism Development: Challenges, Issues and Success Factors. Tour. Recreat. Res. 2015, 30, 27-43. [CrossRef]

25. Wilson, E.; Nielsen, N.; Buultjens, J. From lessees to partners: Exploring tourism public-private partnerships within the New South Wales national parks and wildlife service. J. Sustain. Tour. 2009, 17, 269-285. [CrossRef]

26. Muhanna, E. Sustainable Tourism Development and Environmental Management for Developing Countries. Problems and Perspectives. Probl. Perspect. Manag. 2006, 4, 14-30.

27. GhulamRabbany, M.; Afrin, S.; Rahman, A.; Islam, F.; Hoque, F. Environmental effects of tourism. Am. J. Environ. Energy Power Res. 2013, 1, 117-130.

28. Eagles, P.; Mccool, S.; Haynes, C. Sustainable Tourism in Protected Areas: Guidelines for Planning and Management; IUCN Gland: Cambridge, UK, 2002.

29. Watson, J.E.; Dudley, N.; Segan, D.B.; Hockings, M. The performance and potential of protected areas. Nature 2014, 515, 67-73. [CrossRef] [PubMed]

30. Cole, D.N.; Petersen, M.E.; Lucas, R.C. Managing Wilderness Recreationuse: Common Problems and Potential Solutions; Gen. Tech. Rep. USDA Forest Service; Intermountain Research Station: Ogden, UT, USA, 1987.

31. McNeely, J.A.; Thorsell, J.W. Jungles, Mountains, and Islands: How Tourism can Help Conserve the Natural Heritage. World Leis. Recreat. 1989, 31, 29-39. [CrossRef]

32. Buckley, R.; Pannell, J. Environmental impacts of tourism and recreation in national parks and conservation reserves. J. Tour. Stud. 1990, 1, 24-32.

33. Dowling, R.K. Tourism Planning, People and the Environment in Western Australia. J. Travel Res. 1993, 31, 52-58. [CrossRef]

34. Wight, P.A. Planning for Success in Sustainable Tourism. In Proceedings of the Invited paper presented to "Plan for Success" Canadian Institute of Planners National Conference, Saskatoon, SK, Canada, 2-5 June 1996.

35. Pickering, C.; Hill, W. Impacts of recreation and tourism on plant biodiversity and vegetation in protected areas in Australia. J. Environ. Manag. 2007, 85, 791-800. [CrossRef]

36. Binnewies, R. Palisades: 100,000 Acres in 100 Years; Fordham University Press: New York, NY, USA; Palisades Interstate Park Commission: New York, NY, USA, 2001; p. 70.

37. Szekeres, P. (Ed.) Naturlehrpfade; Institut Für Ökologie: Marburg, Germany, 1999; 53p.

38. Dingwall, P.R. Legislation and international agreements: The integration of the geological heritage in nature conservation policies. In Geological Heritage: Its Conservation and Management; Barretino, D., Wimbledon, W.P., Gallego, E., Eds.; Instituto Tecnológico Geominero de España: Madrid, Spain, 2000; pp. 15-28.

39. Milton, K. Loving Nature: Towards an Ecology of Emotion; Routledge: London, UK, 2002.

40. Schejbal, C. Diversity as a general basis of tourism-System approach. Geosci. Eng. 2015, 61, 18-25. [CrossRef]

41. Hjort, J.; Gordon, J.E.; Gray, M.; Hunter, M.L. Why geodiversity matters in valuing nature's stage. Conserv. Biol. 2015, 29, 630-639. [CrossRef]

42. Raharimahefa, T. Geoconservation and geodiversity for sustainable development in Madagascar. Madag. Conserv. Dev. 2012, 7, 126-136. [CrossRef]

43. Crofts, R. Linking geoconservation with biodiversity conservation in protected areas. Int. J. Geoheritage Parks 2019, 7, 211-217. [CrossRef]

44. Dudley, N. Guidelines for Applying Protected Area Management Categories; IUCN: Gland, Switzerland, 2008. 
45. Migon, P. Geomorphosites and the world heritage list of UNESCO. In Geomorphosites; Reynard, E., Coratza, P., Regolini-Bissig, G., Eds.; Pfeil: Munich, Germany, 2009; pp. 119-130.

46. Dowling, R. Global geotourism-An emerging form of sustainable tourism. Czech J. Tour. 2013, 2, 59-79. [CrossRef]

47. Kubalikova, L.; Kirchner, K. Geosite and Geomorphosite Assessment as a Toolfor Geoconservation and Geotourism Purposes: A Case Study from Vizovická vrchovina Highland (EasternPart of the Czech Republic). Geoheritage 2016, 8, 5-14. [CrossRef]

48. Sharples, C. Concepts and Principles of Geoconservation; Tasmanian Parks \& Wildlife Service: Hobart, Australia, 2002; p. 79.

49. Reynard, E. Scientific research and tourist promotion of geomorphological heritage. Geogr. Fis. E Din. Quat. 2008, 31, 225-230.

50. Zouros, N.C. European geoparks network: Transnational collaboration on earth heritage protection, geotourism and local development. Geoturystyka 2008, 1, 3-22.

51. Hose, T.A. European "Geotourism"-Geological interpretation and geoconservation promotion for tourist. In Geological Heritage: Its Conservation and Management; Barretino, D., Wimbledon, W.P., Gallego, E., Eds.; Instituto Tecnológico Geominero de España: Madrid, Spain, 2000; pp. 127-146.

52. Štrba, L'.; Kršák, B.; Sidor, C. Some Comments to Geosite Assessment, Visitors, and Geotourism Sustainability. Sustainability 2018, 10, 2589. [CrossRef]

53. Štrba, L'. Analysis of criteria affecting geosite visits by general public: A case of Slovak (geo)tourists. Geoheritage 2019, 11, 291-300. [CrossRef]

54. Zwolinski, Z.B.; Stachowiak, J. Geodiversity map of the Tatra National Park for geotourism. Quaest. Geogr. 2012, 11, 99-107. [CrossRef]

55. Dowling, R.K.; Newsome, D. Geotourism; Elsevier Butterworth-Heinemann: Amsterdam, The Netherlands, 2006.

56. Dowling, R.K.; Newsome, D. Global Geotourism Perspectives; Goodfellow Publishers: Oxford, UK, 2010.

57. Arouca Declaration. Available online: https://www.dropbox.com/s/q41gbd0cp2nt73o/Declaration_Arouca_ \%5BEN\%5D.pdf?dl=0 (accessed on 10 November 2019).

58. Geotourism. Available online: https://www.nationalgeographic.com/maps/geotourism/ (accessed on 19 February 2020).

59. McKeever, P.J.; Zouros, N. Geoparks: Celebrating Earth heritage, sustaining local communities. Episodes 2005, 28, 274-278.

60. McKeever, P.; Zouros, N.; Patzak, M. The UNESCO global network of national geoparks. In Geotourism: Tourism of Geology and Landscape; Newsome, D., Dowling, R.K., Eds.; Goodfellow Publishers: Oxford, UK, 2010; pp. 222-230.

61. Cimermanova, I. Geoparks in Slovakia. Acta Geotur. 2010, 1, 34-40.

62. Farsani, N.T.; Coelho, C.; Costa, C. Geotourism and geoparks as novel strategies for socio-economic development in rural areas. Int. J. Tour. Res. 2011, 13, 68-81. [CrossRef]

63. Horváth, G.; Csüllög, G. A new Slovakian-Hungarian cross-border geopark in Central Europe-possibility for promoting better connections between the two countries. Eur. Countrys. 2013, 5, 146-162. [CrossRef]

64. Santangelo, N.; Romano, P.; Santo, A. Geo-itineraries in the Cilento Vallo di Diano Geopark: A Tool for Tourism Development in Southern Italy. Geoheritage 2015, 7, 319-335. [CrossRef]

65. Bloise, A.; Catalano, M.; Critelli, T.; Apollaro, C.; Miriello, D. Naturally occurring asbestos: Potential for human exposure, San Severino Lucano (Basilicata, Southern Italy). Environ. Earth. Sci. 2017, 76, 648. [CrossRef]

66. Ortega-Becerril, J.A.; Jorge-Coronado, A.; Garzón, G.; Wohl, E. Sobrarbe Geopark: An Example of Highly Diverse Bedrock Rivers. Geoheritage 2017, 9, 533-538. [CrossRef]

67. Modrej, D.; Fajmut Štrucl, S.; Hartmann, G. Results of the geointerpretation research in the frame of the Danube GeoTour project. Geologija 2018, 61, 101-110.

68. Ruban, D.A. Karst as important resource for geopark-based tourism: Current state and biases. Resources 2018, 7, 82. [CrossRef]

69. Justice, S.C. UNESCO global geoparks, geotourism and communication of the earth sciences: A case study in the Chablais UNESCO Global Geopark, France. Geosciences 2018, 8, 149. [CrossRef] 
70. Sánchez-Martín, J.M.; Rengifo-Gallego, J.I.; Martín-Delgado, L.M. Characterization of the tourist demand of the villuercas-ibores-jara geopark: A destination with the capacity to attract tourists and visitors. Geosciences 2019, 9, 335. [CrossRef]

71. Gravis, I.; Németh, K.; Twemlow, C.; Németh, B. The Case for Community-Led Geoheritage and Geoconservation Ventures in Māngere, South Auckland, and Central Otago, New Zealand. Geoheritage 2020, 12, 19. [CrossRef]

72. Liščák, P.; Antalík, M. Information System of Important Geosites in the Slovak Republic. Slovak Geol. Mag. 2018, 18, 5-68.

73. 543/2002 Z. z.Zákon o Ochrane Prírody a Krajiny. Available online: https://www.zakonypreludi.sk/zz/2002543 (accessed on 20 February 2020).

74. Vyhláška č. 24/2003 Z. z. Available online: https://www.epi.sk/zz/2003-24 (accessed on 20 February 2020).

75. Lexa, J.; Bezák, V.; Elečko, M.; Eliáš, M.; Konečný, V.; Less, G.; Mandl, G.W.; Mello, J.; Pálenský, P.; Pelikán, P.; et al. Geological Map of Western Carpathians and Adjacent Areas, 1:500,000; Ministry of the Environment of Slovak Republic \& Geological Survey of Slovak Republic: Bratislava, Slovakia, 2000.

76. Kováč, M.; Plašienka, D. Geologická Stavba Oblasti na Styku Alpsko-Karpatsko-Panónskej Sústavy a Pril'ahlých Svahov Českého Masívu; Univerzita Komenského: Bratislava, Slovakia, 2003.

77. Atlas krajiny SR. Available online: https://geo.enviroportal.sk/atlassr/ (accessed on 20 February 2020).

78. Kilík, J. Vývoj územnej ochrany Slovenského krasu. Krásy Slov. 2012, 9-10, 13-15.

79. VGL Databáza. Available online: http://apl.geology.sk/g_vgl/?jazyk=EN (accessed on 20 January 2020).

80. Geodiversity, Geoheritage, Geoconservation-The ProGEO Simple Guide. Available online: http://www. progeo.ngo/downloads/ProGEO_leaflet_EN_2017.pdf (accessed on 20 September 2019).

81. Lukáč, M.; Baláž, B. Placement of geoparks in the system of territorial protection of natural heritage in Slovakia. In Proceedings of the GEOTOUR 2016-International Conference on Geotourism, Mining Tourism, Sustainable Development, and Environmental Protection, Florence, Italy, 18-20 October 2016; Ugolini, F., Marchi, V., Trampetti, S., Pearlmutter, D., Raschi, A., Eds.; IBIMET-CNR: Florence, Italy, 2016; pp. 21-26.

82. Klinda, J.; Stockmann, V. Program Budovania Náučných Chodníkov a Náučných Lokalít v Chránených Územiach SSR. Metodické Pokyny; Ústredie Štátnej Ochrany Prírody: Liptovský Mikuláš, Slovakia, 1984; 48p.

83. Bizubová, M.; Nevřelová, M. Význam náučných chodníkov v krajine a jej ochrane. Acta Environ. Univ. Comen. 2006, 14, 5-10.

84. Ambróz, L. Najstaršie chránené územia na Slovensku. In Príroda a Jej Ochrana v Priereze Času, Zbornik z Medzinárodnej Vedeckej Konferencie; Slovenské Múzeum Ochrany Prírody a Jaskyniarstva: Liptovský Mikuláš, Slovakia, 2018; pp. 137-154.

85. Turistická Infraštruktúra. Available online: https://www.enviroportal.sk/indicator/detail?id=707 (accessed on 27 February 2020).

86. State of the Environment in the Slovak Republic. Available online: https://www.enviroportal.sk/uploads/ report/10521.pdf (accessed on 27 February 2020).

87. McKercher, B. Sustainable Tourism Development_Guiding Principles for Planning and Management; The Hong Kong Polytechnic University: Hong Kong, China, 2003; p. 55.

88. Statistical Office of the SR. Capacity and Performance of Accommodation Facilities in Selected Cities. Data for 2010-2019; Statistical Office of the Slovak Republic: Bratislava, Slovakia. Available online: http: //statdat.statistics.sk/ (accessed on 4 March 2020).

89. Statistical Office of the SR. Accomodation. Tourist Infrastructure. Expenditure in Tourism. Motives and Types of Visitors. Soil Erosion due to Tourism. Cost of Environmental Protection in Tourism. Data for 2000-2014; Statistical Office of the Slovak Republic: Bratislava, Slovakia, 2015.

90. Allan, M.; Dowling, R.K.; Sanders, D. The motivations for visiting geosites: The case of Crystal Cave, Western Australia. Geoj. Tour Geosites 2015, 15, 142-153.

91. Różycka, M.; Migoń, P. Customer-Oriented Evaluation of Geoheritage-On the Example of Volcanic Geosites in the West Sudetes, SW Poland. Geoheritage 2018, 10, 23-37. [CrossRef]

92. Urban, P. Management of Protected Animal Species; Belianum Press: Banská Bystrica, Slovakia, 2013.

93. Ložek, V. Dusledky poznání vývoje přírody a krajiny ČR v holocénu pro ochranu přírody. In Ochrana Přírody a Krajiny v České Republice, Vybrané Aktuálne Problémy a Možnosti Jejich Řešení; Palacký University Olomouc: Olomouc, Czech Republic, 2012; pp. 58-65. 
94. Zweckbronner, G. Mensch, Natur, Maschine im Spiegel dreier Jahrhundertwenden. Ein Vergleich. In Mythos Jahrhundertwende. Mensch, Natur, Maschine in Zukunftsbildern 1800-1900-2000; Verlag: Mannheim, Germany, 2000; pp. 320-333.

95. Lisický, M.J. Ekosozológia. Úvod do Problematiky; Faculty of Natural Sciences, Comenius University Bratislava: Bratislava, Slovakia, 1996.

96. Mihalić, T. Environmental management of a tourist destinationA factor of tourism competitiveness. Tour. Manag. 2000, 21, 65-78. [CrossRef]

97. Kim, M.-S.; Kim, J.; Thapa, B. Influence of Environmental Knowledge on Affect, Nature Affiliation and Pro-Environmental Behaviors among Tourists. Sustainability 2018, 10, 3109. [CrossRef]

98. Muhanna, E. Tourism Development Strategies and Poverty Elimination. Probl. Perspect. Manag. 2007, 5, 37-49.

99. Jamal, T.; Stronza, A. Collaboration theory and tourism practice in protected areas: Stakeholders, structuring and sustainability. J. Sustain. Tour. 2009, 17, 169-189. [CrossRef]

100. Chen, H.; He, L.; Li, P.; Zeng, X.; YOU, C. Relationship of Stakeholders in Protected Areas and Tourism Ecological Compensation: A Case Study of Sanya Coral Reef National Nature Reserve in China. J. Resour. Ecol. 2018, 9, 164-173.

101. Kisi, N. A Strategic Approach to Sustainable Tourism Development Using the A'WOT Hybrid Method: A Case Study of Zonguldak, Turkey. Sustainability 2019, 11, 964. [CrossRef]

102. Pickering, C.M.; Harrington, J.; Worboys, G. Environmental Impacts of Tourism on the Australian Alps Protected Areas. Mt. Res. Dev. 2003, 23, 247-254. [CrossRef]

103. Štrba, L.; Kršák, B.; Sidor, C. Motivation of general public (geo)tourists to visit geosites: A case study from Slovakia. In Proceedings of the GEOTOUR 2016-International Conference on Geotourism, Mining Tourism, Sustainable Development, and Environmental Protection, Florence, Italy, 18-20 October 2016; Ugolini, F., Marchi, V., Trampetti, S., Pearlmutter, D., Raschi, A., Eds.; IBIMET-CNR: Florence, Italy, 2016; pp. 206-209.

104. Csorvási, N. Motivation for participating in Geotours. In Proceedings of the GEOTOUR 2016-International Conference on Geotourism, Mining Tourism, Sustainable Development, and Environmental Protection, Florence, Italy, 18-20 October 2016; Ugolini, F., Marchi, V., Trampetti, S., Pearlmutter, D., Raschi, A., Eds.; IBIMET-CNR: Florence, Italy, 2016; pp. 200-205.

105. Štrba, L'.; Kršák, B.; Sidor, C. Factors perceived by tourists during geosite visits: A case study from Slovakia. In Proceedings of the IXth International Tourism Congress (ITC'17), Peniche, Portugal, 29-30 November 2017; IPLeiria: Peniche, Portugal, 2017; pp. 569-578.

106. Geoparks of the Slovak Republic. Available online: http://geopark.sk/wp-content/uploads/2018/12/priloha_2. pdf (accessed on 22 March 2020).

107. Novohrad-Nograd Geopark. Available online: http://www.globalgeopark.org/aboutGGN/list/HungarySlovakia/ 6438.htm (accessed on 23 March 2020).

108. Information on the Implementation of the Updated Concept of Geoparks in the Slovak Republic. Available online: http://www.geopark.sk/wp-content/uploads/2019/08/1.pdf (accessed on 4 March 2020).

109. Černecký, J.; Gajdoš, P.; Šuplerová, J.; Halada, L.; Mederly, P.; Ulrych, L.; Ďuricová, V.; Švajda, J.; Černecká, L'.; Andráš, P.; et al. Ecosystems in Slovakia. J. Maps 2020, 16, 28-35. [CrossRef]

110. Solár, J. One hundred years of nature conservancy in Slovakia. Oecol. Mont. 2019, 28, 56-57.

111. Izakovičová, Z.; Świader, M. Building ecological networks in Slovakia and Poland. Ekológia (Bratislava) 2017, 36, 303-322. [CrossRef]

112. Považan, R.; Getzner , M.; Švajda, J. Value of Ecosystem Services in Mountain National Parks. Case Study of Vel'ká Fatra National Park (Slovakia). Pol. J. Environ. Stud. 2014, 23, 1699-1710.

113. Macko, J.; Blahútová, D.; Stollárová, N. Space for environmental education in the system of secondary education in Slovakia. Informatologia 2013, 46, 256-260.

114. Dowling, R.K. Geotourism's Global Growth. Geoheritage 2011, 3, 1-13. [CrossRef]

115. Robinson, A.M. Geotourism: Who is the Geotourist? Inaugural National Conference on Green Travel, Climate Change and Ecotourism, Adelaide SA, Australia, November 2008. Available online: https: //sustain.pata.org/wp-content/uploads/2015/02/Geotourism.pdf (accessed on 20 March 2020).

116. Mao, I.; Robinson, A.M.; Dowling, R.K. Potential geotourists: An Australian case study. J. Tour. 2009, 10, $71-80$. 
117. Fonseca Filho, R.E.; Ribeiro, G.S. Geotourist profile of "Serra do Rola-Moça" State Park (MG, Brazil). Revista. Bras. Ecotur. 2016, 9, 471-496.

118. Rivero, M.S.; Rangel, M.C.R.; Martín, J.M.S. Geotourist Profile Identification Using Binary Logit Modeling: Application to the Villuercas-Ibores-Jara Geopark (Spain). Geoheritage 2019, 11, 1399-1412. [CrossRef]

119. Allan, M.; Shavanddasht, M. Rural geotourists segmentation by motivation in weekends and weekdays. Tour. Hosp. Res. 2019, 19, 74-84. [CrossRef]

(C) 2020 by the authors. Licensee MDPI, Basel, Switzerland. This article is an open access article distributed under the terms and conditions of the Creative Commons Attribution (CC BY) license (http://creativecommons.org/licenses/by/4.0/). 